\title{
History Woyla Arc of the Garba Complex: Implications for Tectonic Evolution of the South Sumatra Region, Indonesia
}

\author{
Idarwati $^{1,2}$, Heru Sigit Purwanto², Edy Sutriyono', Carolus Prasetyadi ${ }^{2}$, Stevanus Nalendra Jati ${ }^{1}$ \\ ${ }^{1}$ Geology Study Program, Faculty of Engineering, University of Sriwijaya, Indralaya, Indonesia \\ ${ }^{2}$ Department of Geology, Faculty of Mineral Technology, University of Pembangunan Nasional “Veteran”, Yogyakarta, Indonesia \\ Email: idarwati@ft.unsri.ac.id
}

How to cite this paper: Idarwati, Purwanto, H., Sutriyono, E., Prasetyadi, C., \& Jati, S. N. (2021). History Woyla Arc of the Garba Complex: Implications for Tectonic Evolution of the South Sumatra Region, Indonesia. Journal of Geoscience and Environment Protection, 9, 118-132.

https://doi.org/10.4236/gep.2021.912008

Received: October 31, 2021

Accepted: December 26, 2021

Published: December 29, 2021

Copyright $\odot 2021$ by author(s) and Scientific Research Publishing Inc. This work is licensed under the Creative Commons Attribution International License (CC BY 4.0)

http://creativecommons.org/licenses/by/4.0/

\begin{abstract}
Studies on outcrop-scale structures have been conducted at the Garba complex. This study aims to add the high-resolution of the South Sumatra region to reconstruct the structural geology and implications of tectonics for the region. The study area is commonly referred to as crystalline basement highs forming the southwestern boundary of the Paleogene South Sumatra basin. The structures commonly show the NW-SE, NNW-SSE, and ENE-WSW trends. The methodology used includes field mapping, analysis of Digital Elevation Model (DEM), petrography, and X-ray fluorescence (XRF). The major fractures include wrench slip, reverse, and normal faults, while the observable microstructures comprise pull-apart calcite veins, shear joints, boudins, parasitic folds, and the augens. The earlier structuring episode was probably related to crustal extension, perhaps associated with the Paleogene rifting that occurred along the western margin of Sundaland. In the Late Neogene, tectonic compression took place in the entire region, allowing inversion of the Pre-Tertiary sequence. As compression waned in the Pleistocene, extension commenced, and a number of the ENE-WSW tensional block faulting developed and intersected the older NNW-SSE alignments. It is important to note that the latest tectonic event in conjunction with deep erosional denudation had likely exhumed the terrain and eventually shaped the present-day fractured and rough landforms in the study area.
\end{abstract}

\section{Keywords}

Basement High, Crystalline Sequence, Structure, Tectonics

\section{Introduction}

The present study area shows a structural high that lies at the Late Neogene Ba- 
risan Orogeny, which stretches along the western portion of the island of Sumatra. The region has commonly referred to as the southwestern boundary of the Paleogene South Sumatra basin (Bishop, 2001; Barber \& Crow, 2003). Several studies reported that the Garba terrain is constituted by the pre-tertiary rock units, such as low-grade metamorphic rocks, mélange, intrusive and extrusive bodies, and metasediment sequence, which are similar to those underneath the adjoining Paleogene South Sumatra basin (Adiwidjaja \& de Coster, 1973; de Coster, 1974; Pulonggono et al., 1992; Gafoer et al., 1994; Barber, 2000; Barber \& Crow, 2003; Barber et al., 2005; Sagita et al., 2008).

The strongly similar lithologies beneath the South Sumatra back-arc basin with the outcropping rock units within the Garba block confirm that the two regions are essentially a single entity (Adiwidjaja \& de Coster, 1973; de Coster, 1974); and likely have interrelated deformation history. The terrain has also been interpreted as the southwestern extension of the basinal basement unit (Barber et al., 2005). Hence, it is important to note that studies on structural configuration recorded in the outcrop-scale exposures may provide a powerful tool for better understanding the deformation styles within the unexposed basement sequence of the back-arc setting, which has long been recognized as an oil-gas producing depocenter. Such a study may become fundamental, especially in exploring a deeper reservoir within the basinal section (Guttormsen, 2010; Budiman et al., 2011; Sunarjanto \& Widjaja, 2013; Risyad et al., 2017).

In a regional context, the Garba complex has been interpreted based on a wide range of perspectives. (Pulonggono et al., 1992) considered that the terrain was uplifted due principally to extension taking place in Paleogene time. (Barber et al., 2005) stated that the area was a site of collision complex between Sibumasu and Indochina block. (Hall, 2014) suggested that Woyla volcanic arc, including the present Garba complex, resulted from subduction between Mesotethys and Cenotethys. This study will be illustrated in modeling the magma series on the Woyla arc based on petrographic and geochemical data of rocks using the XRF method. The more recent work reported that there was renewed subduction during the post-converging episode between the Woyla volcanic arc and Sundaland in the island of Sumatra, in which the event resulted in Situlanglang ridge and Insu mélange complex (Advokaat et al., 2018). The recently conducted work was to identify the geological structures recorded within the rock sequence, which may explain tectonic episodes responsible for the exposure of the Garba block. Thus, this study aimed principally to reconstruct the structural architecture and the tectonic evolution of the terrain in Tertiary time. The microstructure analysis and the evolutionary geochemical data in Garba complex tectonic studies are very helpful for future research.

\section{Materials and Methods}

This study employed two practical approaches: lineament mapping and ground investigation to recognize strain distributions throughout the crystalline rock 
exposures at the Garba complex. Data collection methods and field sampling methods are the keys in reconstructing the tectonic evolution model in this study which is supported by DEM analysis, petrography, and igneous rock geochemistry in the form of XRF. Delineation of major alignments was interpreted using the Digital Elevation Model (DEM) as suggested by several workers (Abe et al., 2011; Chenrai, 2012; Khajavi et al., 2014; Meixner et al., 2018). The present study employed the DEM was available in Seamless National DEM or DEMNas at tides.big.go.id provided by the Indonesian Geospatial Agency. The system provided three data sources with different resolutions, such as IFSAR $(5 \mathrm{~m})$, TERRASAR-X (5 m), and ALOS PALSAR $(11.25 \mathrm{~m})$ with additional mass-point of vertical datum EGM2008. Meanwhile, to improve the DEM resolution up to 0.27 arc second $(8.1 \mathrm{~m})$, this work has compiled those accessible sources. Interpretation of structures relies mainly on two aspects, positive alignments expressed by shaded topographic relief of ridges and negative features represented by the valley and river patterns (Chenrai, 2012; Meixner et al., 2018; Abed, 2013). Figure 1 shows the result of DEM interpretation for the currently studied area. In addition, the DEM analysis was then compiled with the results of the ground investigation within the study area. Given the interpreted DEM, several key areas have been identified for further structural observations, particularly those of Gilas, Saka, Malau Sarangan, Lubar, Rambang, Pisang, Sui, Liki and Meninting alignments (Figure 1).

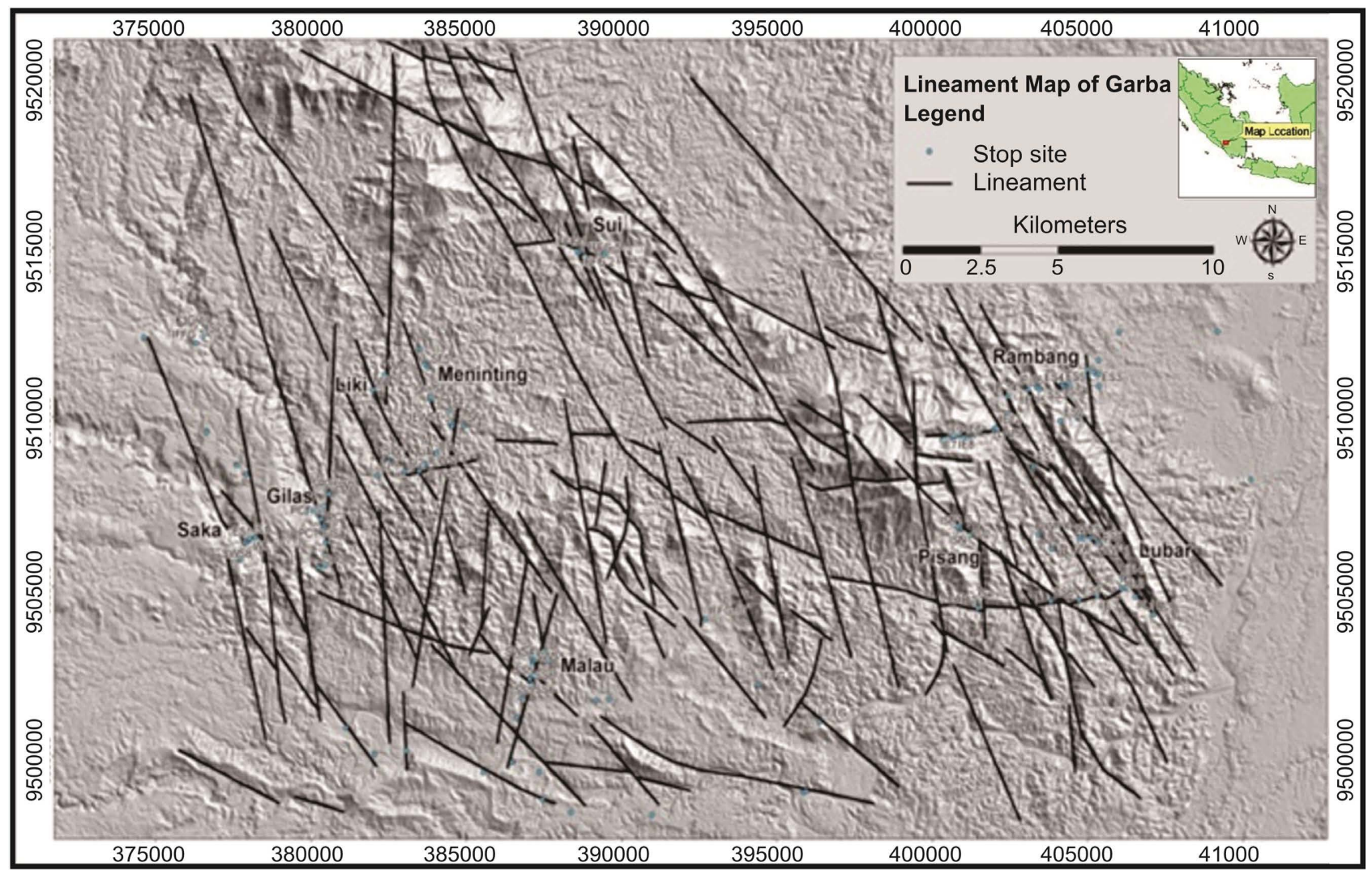

Figure 1. DEM analysis was used to identify regional alignments as the key areas for further structural description on outcrops. 
Many techniques for microstructural analysis can be applied to determine the shear sense in ductile deformation (Berthé et al., 1979; Bouchez et al., 1983; Lister \& Snoke, 1984; Simpson, 1985). Some of these techniques, before they can be applied in analysis, require oriented rock sampling data. Oriented Sampling is a rock sampling technique mainly focused on determining shear sense, whether it is ductile or brittle deformation. The results of this sample will be continued into the thin section process and can be used in the microstructural analysis. The stages of the sampling process include rock measurements, sample marking, and cutting slabs in petrographic analysis. The scanline method was used to measure orientation, length, aperture, spacing, and identify mineral fills in fractures along the given line (Priest \& Hudson, 1981; Priest, 1993). The square system was undertaken mainly within the damage zones (Priest, 1993). Additionally, the technique was adopted particularly to identify the density and diagenetic relations among the internal structures recorded in rocks (Brodie et al., 2007; Sanderson \& Nixon, 2015; Hooker et al., 2018). The construction and interpretation of the strain styles of The Garba sequence utilized a set of data gained from both linear scanline and square measurements as suggested by several workers (Mozley \& Goodwin, 1995; Heynekamp et al., 1999; Rawling \& Goodwin, 2006). Classification of fractures was based on the geometrical, kinematic, and mechanical parameters (Peacock et al., 2016). In addition, computer-aided analysis of structures in the present study has employed the stereonet V10 (Allmendinger et al., 2011; Cardozo \& Allmendinger, 2013) and FaultKin8 programs (Allmendinger et al., 2011; Marrett \& Allmendinger, 1990). These packages of software are available at http://www.geo.cornell.edu/geology/faculty/RWA/programs/.

Geochemical analysis of igneous rocks is very helpful in determining the magma evolution series in solving problems that occur in the Woyla volcanic arc. This analysis was carried out at the Geological Survey Central Laboratory using the XRF method.

\section{Results and Discussion}

\subsection{Brief Overview of the Geology}

Several studies have described the Garba complex as a basement high that consists predominantly of schist, phyllite, mélange, intrusive and extrusive rocks, and metasediments (de Coster, 1974; Barber \& Crow, 2003; Barber et al., 2005; Sagita et al., 2008). These crystalline rocks constitute the Garba, Situlanglang, Insu, Tarap, and Granite Formations (Gafoer et al., 1994). The low-grade metamorphic rocks such as schist and phyllite were likely formed at shallower depths relative to the former subduction zone, while the tectonic mélange is thought to represent remnants of what were originally formed platform sediments that were subsequently mixed up tectonically in the paleo-subduction zone. This scenario is reliable with the published tectonic models (Barber et al., 2005) and (Hall, 2014), who postulated that the region was a site of the pre-Tertiary subducted plate. Allows for crustal thickening that can initiate collision-associated magmatism in the 
range $91.3 \pm 1.9$ million years old (Handini et al., 2017).

Results of K/Ar dating from the sampled monzonite, gabbro, and granite reveal radiometric ages ranging from 117 - 79 Ma (McCourt \& Cobbing, 1993; Gafoer et al., 1994; McCourt et al., 1996). The radiolarian analysis from the outcropping chert of the Situlanglang ridge suggests that the sequence is Middle Triassic (Munasri et al., 2015). This interpretation is consistent with the earlier study (Barber \& Crow, 2003). Regionally, the pre-tertiary sequences have been considered as a part of Woyla Group and West Sumatra basement (Barber et al., 2005; Van Hinsbergen et al., 2011; Metcalfe, 2013; Li, J. et al., 2018). According to (Metcalfe, 2011) the convergence of Woyla and West Sumatra crystals commenced during the Early Cretaceous, consistent with the kinematic plate reconstruction (Hall, 2014).

Little study on the outcrop-scale structures has been undertaken in the Garba block. Thus the area remains poorly understood structurally. Idarwati et al. (Idarwati et al., 2018) have reported their preliminary studies on vicinity structures. It is worth noting that the structure of the region is likely to be more complex than interpreted in the present work. Indeed, the previous studies commonly emphasized regional observations. The terrain is generally referred to as part of the present Woyla Group. It is apparent from the published reports that interpretations on the origin and time of migration of the proto Woyla Group into its present location appear distinctive. In the Late Jurrasic-Early Cretaceous, the region was an intra-oceanic arc and or accretionary complex that became sutured to Sumatra (Wajzer et al., 1991; Barber, 2000). The more recent works reported that the Woyla arc collided and subducted underneath the western Sumatra segment in the Middle Cretaceous time, creating a new magmatic arc that yielded the Garba succession (Torsvik et al., 2012; Advokaat et al., 2018). This scenario seems consistent with the earlier studies (Cameron et al., 1980), who suggested that the western portion of the Woyla arc overlies the Sikuleh continental fragment. However, Barber and Crow (Barber \& Crow, 2003) stated that the microcontinent is part of the Woyla block.

\subsection{Tectonics}

The structure that developed in the Paleozoic is dominated by parasitic folds with shortening from 7.74 to $61.45 \mathrm{~cm}$. That indicates that West Sumatra has been hit by a contraction ratio of $0.57 \%-0.84 \%$, including Middle Cretaceous Woyla Arc accretion, Paleogene crust extension, to Neogene compression (Hall, 2014; Advokaat et al., 2018). Based on this structure, it can be interpreted that the tectonic transport of the Tarap Formation from the NW-SE direction and the fault forms a half-graben model in the WNW direction as well as being in contact with Mesozoic units found on the Malau River, this model as shown in Figure 2. The recent subduction phase of the Sunda Trench in the Middle Cretaceous (Advokaat et al., 2018) and the extension of the Paleogene crust (Hall, 2014) are thought to be the most responsible for the dynamics of West Sumatra 

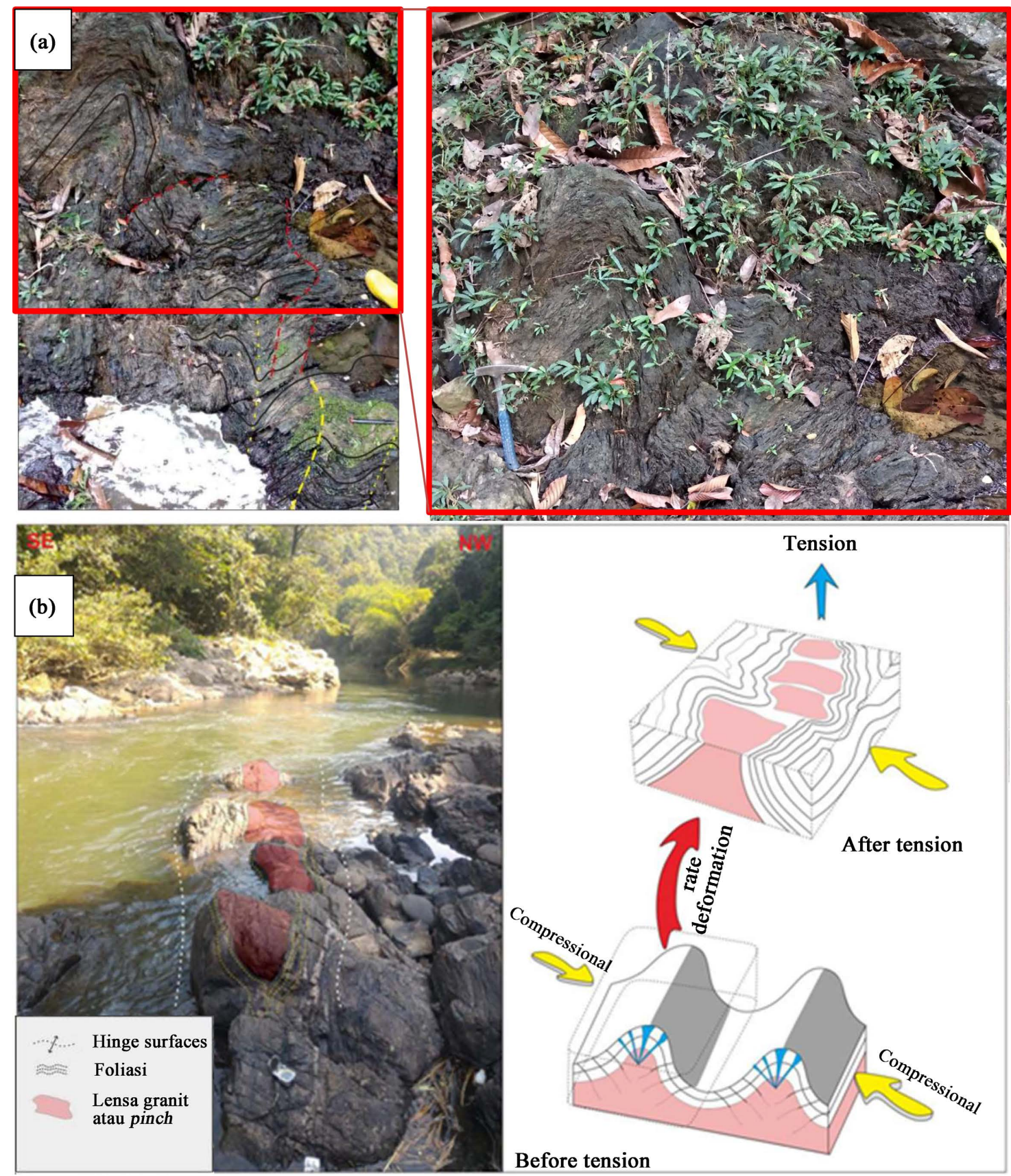

Figure 2. (a) Outcrop of parasitic fold in Malau SWS 09; (b) Pinch out structure on boudin granite with phyllite at Gilas IWD 05.

before the formation of thick sedimentary deposits in the South Sumatra Basin or known as extensional basement involved.

The Mesozoic rocks exposed in the Garba Complex are dominated by igneous rocks consisting of gabbro, basalt, andesite to the youngest granite intrusion in the Cretaceous. Structural control in Mesozoic rocks is the normal fault and strike-slip fault. Normal faults develop in the east, namely Pisang Fault and Lubar Fault, with internal features (pull apart calcite vein and macro boudin). Interconnecting normal faults and strike-slip faults are found in the accretion area. 


\subsection{Permian-Triassic Period}

During this period, the Sundaland Continental core blocks (Sibumasu, Sukhotai Arc, Simao, and Indochina) amalgamated and collided with the South \& North China Blocks to form Proto-East and SE-Asia. Later, the Paleo-Tethys closed and formed the Songpan Gazi basin. Meanwhile, Meso-Tethys moves away from the ocean basin and subducts towards the NE (Continental Block Sundaland) and towards the SW (India-Australian Margin, Lakhsa, Lhasa, East Java-West Sulawesi \& SW Borneo blocks from Gondwana (Metcalfe, 2017). One of the Sundaland Continental Blocks is Cathasyian West Sumatra. Cathaysian West Sumatra is part of the Sukhotai Arc, where the position in this period is outside the Sibumasu Block. This change is due to the movement of strike-slip translation in the Late-Triassic (Barber \& Crow, 2009).

The presence of schist, phyllite, and in some places, a boudine of marble and quartzite make up the West Sumatra Block rocks in Garba. Thirty-five rock samples were analyzed using the petrographic method to determine the mineral composition that helps name the rocks that build up West Sumatra. Green schist with a nematoblastic texture composed of chlorite, quartz, muscovite, calcite, opaque minerals, and local chalcopyrite found in Malau, Rambangnia, and Simpang. Mica schist was found in Bungin with nematoblastic texture, actinolite schist in Tara river, and amphibole schist in Celau river. Meanwhile, the presence of graphite phyllite and chlorite phyllite in the Malau, Tara, and Celau rivers indicates that the presence of actinolite minerals is interpreted as retrogradation of plagioclase minerals as a result of rock uplift in the Mesozoic.

In addition to these events, the Woyla Arc was formed during the Late-Triassic, which is part of the intra-oceanic arc. This block is in the SW-Sundaland margin in the Tethys Cenozoic, along with the Kohistan-Ladakh Arc, formed during the Late-Triassic (Metcalfe, 2011, 2013).

The chert formed in Situlalang is evidence of the discovery of Triassic radiolaria (Munasri et al., 2015). From petrography, we found chert with a non-clastic and amorphous texture containing microcrystalline in the form of radiolarians surrounded by reddish-brown oxide minerals.

\subsection{Early Jurassic-Cretaceous Period}

In this period, the Ceno-Tethys split occurred during the Late-Jurassic, due to the spreading of the intra-oceanic arc and the movement of the transform fault from Gondwana (Metcalfe, 2017). This phase is correlated with the Woyla arc fragment in the Oceanic lithosphere that separates from Eurasia (Margin Sundaland) and produces the Ngalau Ocean at $130 \mathrm{Ma}$ (Barber et al., 2005; Torsvik et al., 2012; Advokaat et al., 2018). The Woyla Arc is an intra-oceanic arc fragment, along with the Kohistan-Ladakh Arc which was formed during the Late-Triassic (Metcalfe, 2011, 2013).

Observations of petrographic incisions made on 45 samples on the Saka, Lubar, Rambangnia, and Melat trajectories showed variations in gabbro, basalt, red 
limestone, chert, claystone, and sandstone. The presence of gabbro and basalt igneous rocks with anhedral, holocrystalline crystals with fine to medium phaneric granularity, mineral composition in the form of Ca-plagioclase, chlorite, quartz, opaque minerals, calcite, sericite, a little augite, and some places there is chalcopyrite. Petrographic incisions in siliciclastic sedimentary rocks in the form of sandstones in the Saka River are characterized by an angular-rounded grain shape, with floating contact grains supported by a matrix of illite lithic, opaque minerals, silt-sized materials, chlorite, and talc.

Based on geochemical analysis using XRF (Figure 3; Figure 4) from the samples IF2, IF3, and G17, it was known that these samples had a $\mathrm{SiO}_{2}$ value of \pm $65 \%$. The $\mathrm{Al}_{2} \mathrm{O}_{3}$ is presence quite high, this is manifested in rocks with many muscovite minerals appearing. The $\mathrm{K}_{2} \mathrm{O}(\%)$ in the three samples showed $<3.2 \%$ with $\mathrm{K}_{2} \mathrm{O}$ values $\pm 4.5 \%$., in samples IF2 and G17. However, in the IF3 sample

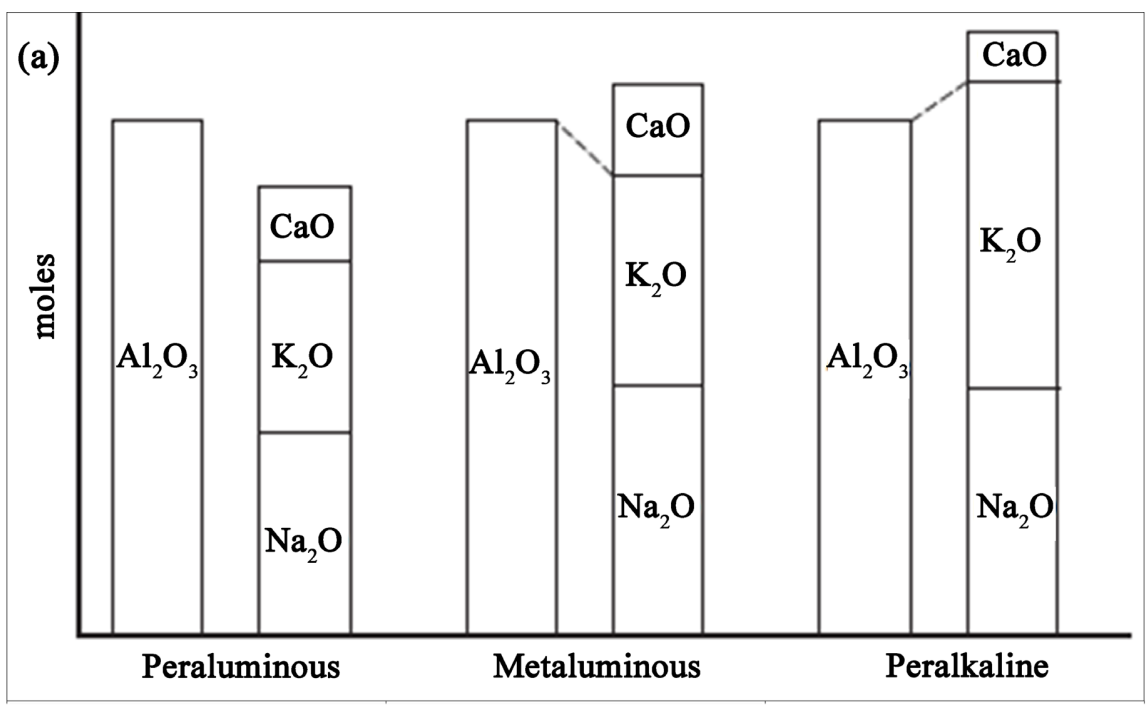

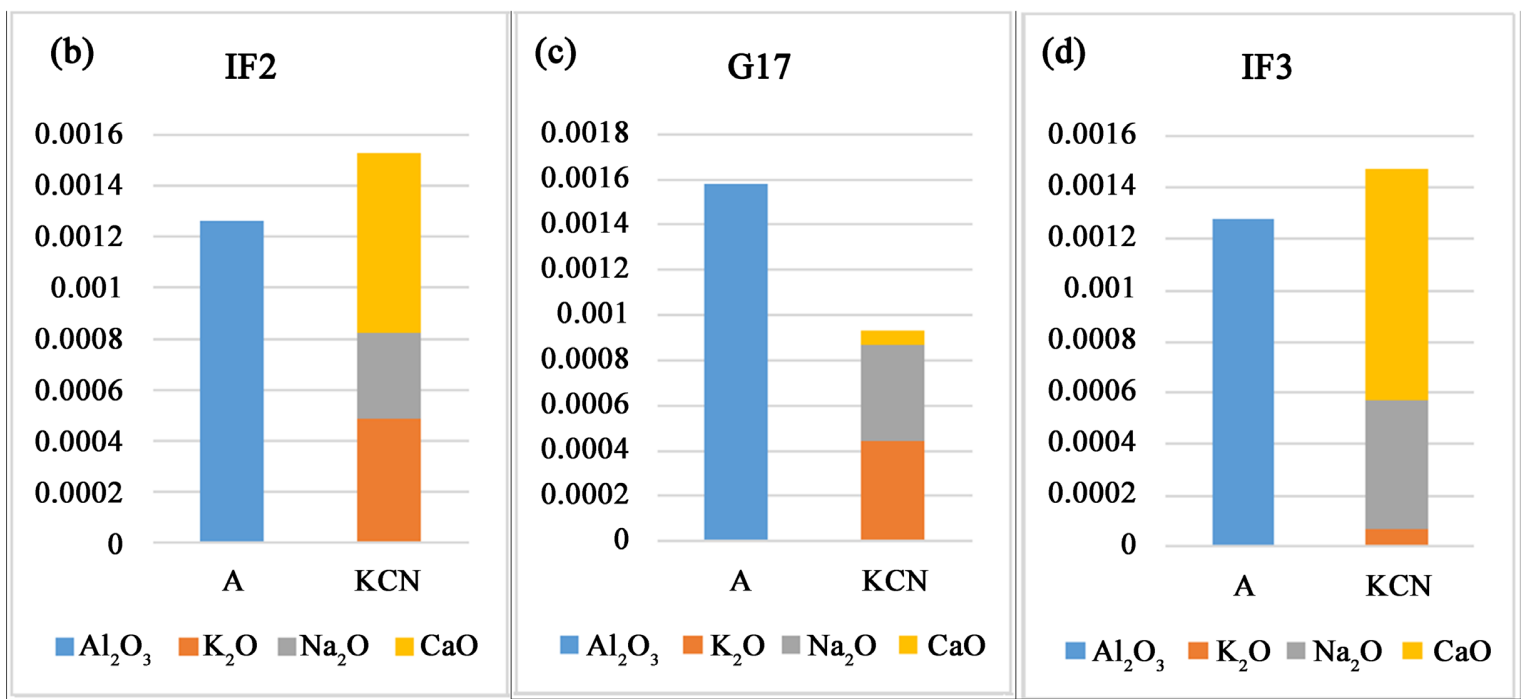

Figure 3. (a) Alumina saturation diagram based on the molar ratio of $\mathrm{Al}_{2} \mathrm{O}_{3} /\left(\mathrm{K}_{2} \mathrm{O}+\mathrm{Na}_{2} \mathrm{O}+\mathrm{CaO}\right)$ ("A/CNK") according to Shand (1972), in Winter (2013); (b) A/CNK diagram for sample IF2; (c) A/CNK diagram for sample G17; (d) A/CNK diagram for sample IF3. 

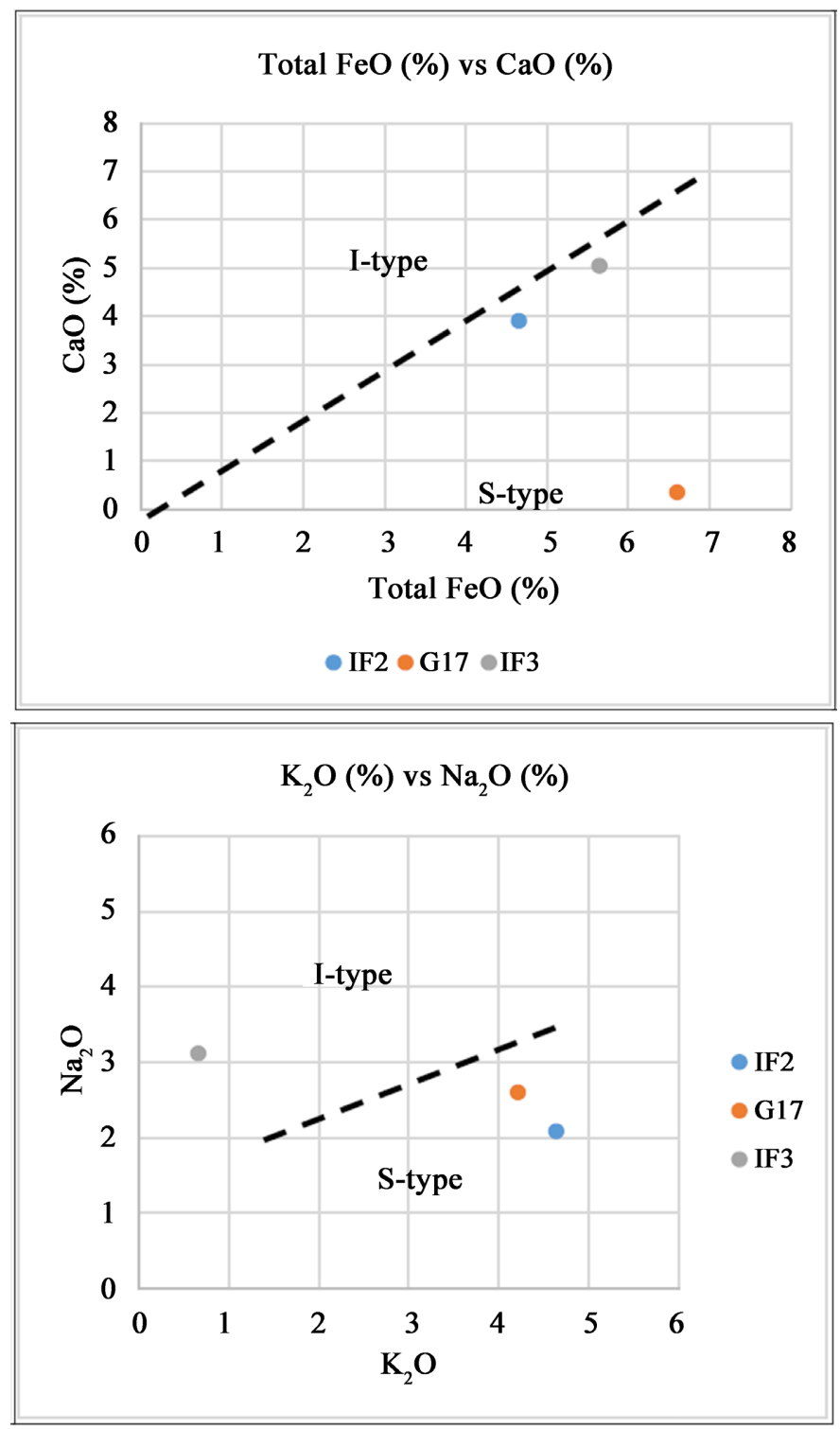

Figure 4. Diagram of $\mathrm{FeO}(\%)$ vs. $\mathrm{CaO}(\%)$ and $\mathrm{K}_{2} \mathrm{O}(\%)$ vs. $\mathrm{Na}_{2} \mathrm{O}(\%)$ of IF2, IF3, and G17 samples based on Chappel and White (2001).

the $\mathrm{K}_{2} \mathrm{O}$ value is less than $1 \%$. The $\mathrm{A} / \mathrm{KCN}$ diagram (Molar ratio $\mathrm{Al}_{2} \mathrm{O}_{3} / \mathrm{K}_{2} \mathrm{O}+$ $\mathrm{CaO}+\mathrm{Na}_{2} \mathrm{O}$ ) shows that this rock is peraluminous with a ratio value of 1.6 in the G17 sample and metaluminous with a comparison value of 0.82 and 0.86 in the IF2 and IF3 samples. In general, the results from the $\mathrm{K}_{2} \mathrm{O}(\%) \mathrm{vs}^{\mathrm{Na}} \mathrm{Na}_{2} \mathrm{O}(\%)$ and $\mathrm{CaO}(\%)$ vs $\mathrm{FeO}(\%)$ plot diagrams show fairly low results, however the IF3 sample on the $\mathrm{K}_{2} \mathrm{O}(\%)$ vs $\mathrm{Na}_{2} \mathrm{O}(\%)$ diagram shows a high value.

The exposures of mélange complex comprise mainly of andesite, marble, serpentinite, greenschist, and black mudstone. As the outcrops contain mylonites, boudins, porpyroclast, and breccias, it implies a significant structural control in the region. The boudin structure shows a general trend to the NW-SE direction $\left(\mathrm{N} 140^{\circ} \mathrm{E}\right)$ with sigmoid and lenses patterns. It is also notable that the boudin spacing gradually widens to the NW, suggesting a northwestward increase in 
shear strain. The interpretation is consistent with the observation that the boudin structure appears to have changed in geometry from flattening in the SE to shear band in the NW (Figure 5). According to (Goscombe et al., 2004) such structural features are classified as symmetric types (RHS).

\subsection{Early Jurassic-Cretaceous Period}

This period was marked by merging the Woyla Block fragments with SW Sundaland (West Burma, West Sumatra, \& Sibumasu) (Metcalfe, 2017). This phase resulted from the subduction that occurred during the Middle Cretaceous (95 $\mathrm{Ma}$ ) and formed a new Magmatic arc (one segment is interpreted as Garba Complex) (Torsvik et al., 2012; Advokaat et al., 2018). Refer to (Handini, 2017) in this period also associated with magmatism in $91.3 \pm 1.9$ million years old. This Petrographic analysis in the Liki, Pressa, Sui, and Kiti areas shows that granite with anhedral to subhedral crystal form, with a crystal size of $0.1-5 \mathrm{~mm}$, is supported by dominant orthoclase minerals, quartz, plagioclase, K-feldspar, sericite, biotite, calcite, chlorite, muscovite, opaque minerals, hornblende and small amounts of talc in some locations. That is confirmed by XRF analysis, as many as two samples analyzed, namely Liki G17 and Pisang IF2 on granite rocks, indicating that magmatism in the continental arc occurred due to plate collisions (after subduction). The magmatism affinity series at these two locations shows the type of Hi-K Calc-Alkaline series (Peccerillo \& Taylor, 1976). Along the Woyla Arc and SW-Sundaland contact boundaries, several volcanic paths and dextral strike-slip faults (Sumatra Fault Systems) are produced.

\subsection{Paleogene Extension Period}

The Paleogene period is characterized by the extension and inversion of the
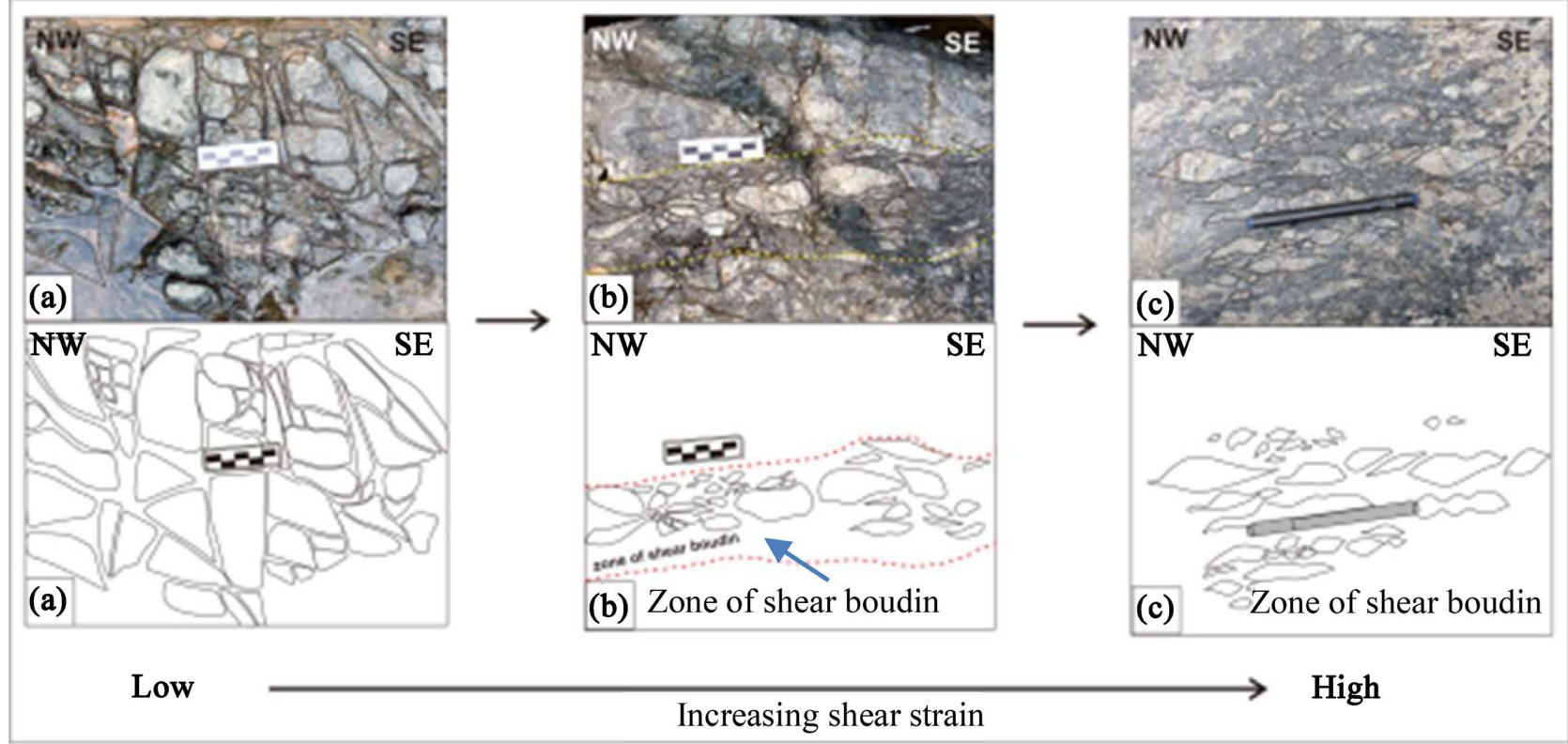

Figure 5. (a) and (b) Comparison of boudin in IE 04; (c) WI 1. Diagram of the relationship between shear strain and boudin geometry. 
basin. As a result, some Woyla Group fragments were deformed and formed normal faults with an N-S orientation.

\subsection{Late Neogene Orogeny Period to Extended Pleistocene}

This period is marked by the Uplift of the Orogeny Row, resulting from the compressional development that developed during the Neogene period (Pulonggono et al., 1992). As a result, reactivation of normal faults previously developed during the Paleogene, one of the products is the Meninting fault.

This Pleistocene Extension period is characterized by an extension phase caused by the Exhumation process of the Plutonic Garbage Block. This block intrudes Volcanic Garba and Tarap Fm. Middle-Late Cretaceous (115 - $79 \mathrm{Ma}$ ). Garba Pluton is the result of the volcanism of the Woyla Group Block with West Sumatra (Barber et al., 2005). The process is interpreted to come from the effect of increasing magmatism activity. Thus, this implies that plutonic granite, which was previously still on the surface, was then exposed through the Sumatra Fault Zone fracture zone.

- This extension phase produces a series of electric faults divided into two parts, west, and east. First, the western part is composed of the Saka, Gilas, and Malau blocks. Meanwhile, the eastern blocks are Rambang and Lubar. The block is affiliated with the Woyla Group (continental arc, magmatic arc, and oceanic accretionary arc) with West Sumatra. The orientation of these blocks is relatively NW-SE, and the fault dip towards the granite detachment tends to become shallower (shallow dip).

- The Sumatra Fault System (SFS) development is NW-SE oriented and has implications for the Pluton Granite block pattern to become Transtensial. The main control is the dextral strike-slip fault, which is correlated with the Lematang Fault in the direction of WNW-ESE and the Kikim Fault with the orientation of N-S (Pulonggono et al., 1992).

\section{Conclusion}

The present study area is composed of heterogeneous rocks, predominantly igneous and metamorphic successions. Based on XRF data shows two different igneous rock environments in the Woyla that indicate different formation times, namely tholeiitic to calc-alkaline in the Jurassic-Early Cretaceous and hi-k calcalkaline series in the Late Cretaceous. The region is very complex structurally as it has been subjected to poly-phased deformation, resulting in blocky and rough exposures. The prominent fractures that have been recognized in outcrops include those of Gilas and Saka, Malau Sarangan, Lubar, Rambang, Pisang, Sui, Liki, and Meninting faults. Observations on the outcropping structures reveal that the area might have been subjected to at least three episodes of tectonic events during the Tertiary. In the Paleogene, the terrain was dominated by an extensional regime that might have been responsible for developing the NW-SE striking alignments and the formation of sedimentary basins. In the Late Neo- 
gene, the Barisan orogeny commenced, and uplift of the Pre-Tertiary sequence and the inversion of the adjacent Paleogene South Sumatra basin took place. As the orogenic compression ceased in Pleistocene, the crustal extension occurred, and a number of NNW-SSE-directed tensional fracturing developed within the Garba block. Eventually, the Pleistocene deep and extensive erosional denudation exhumed and shaped the recent landforms. This study obtained a highresolution structure compared to previous studies that have been carried out. The microstructure and evolutionary geochemical data in Garba complex tectonic studies are very helpful for future research.

\section{Acknowledgments}

The authors would like to thank the editor and anonymous reviewers for their comments that helped improve the quality of this work. Also, thanks to Endang Wiwik Dyah Hastuti, Wahidin Z., Fery Nugroho, Aditya Kurniawan, and Nanda Ajeng Nurwantari who has provided input and discussion.

\section{Conflicts of Interest}

The authors declare no conflicts of interest regarding the publication of this paper.

\section{References}

Abe, S., Van Gent, H., \& Urai, J. L. (2011). DEM Simulation of Normal Faults in Cohesive Materials. Tectonophysics, 512, 12-21. https://doi.org/10.1016/j.tecto.2011.09.008

Abed, R. S. (2013). Watershed Delineation in GIS Environment. International Journal of Enhanced Research in Science Technology and Engineering, 2, 48-54.

Adiwidjaja, P., \& de Coster, G. L. (1973). Pre-Tertiary Paleogeography and Related Sedimentation in South Sumatra. In Proceedings of the Indonesian Petroleum Association, 2nd Annual Convention (pp. 89-103). Indonesian Petroleum Association. https://doi.org/10.29118/IPA.722.89.103

Advokaat, E. L., Bongers, M. L., Rudyawan, A., BouDagher-Fadel, M. K., Langereis, C. G., \& van Hinsbergen, D. J. J. (2018). Early Cretaceous Origin of the Woyla Arc (Sumatra, Indonesia) on the Australian Plate. Earth and Planetary Science Letters, 498, 348-361. https://doi.org/10.1016/j.epsl.2018.07.001

Allmendinger, R. W., Cardozo, N., \& Fisher, D. M. (2011). Structural Geology Algorithms: Vectors and Tensors. Cambridge University Press. https://doi.org/10.1017/CBO9780511920202

Barber, A. J. (2000). The Origin of the Woyla Terranes in Sumatra and the Late Mesozoic Evolution of the Sundaland Margin. Journal of Asian Earth Sciences, 18, 713-738. https://doi.org/10.1016/S1367-9120(00)00024-9

Barber, A. J., \& Crow, M. J. (2003). An Evaluation of Plate Tectonic Models for the Development of Sumatra. Gondwana Research, 6, 1-28. https://doi.org/10.1016/S1342-937X(05)70642-0

Barber, A. J., \& Crow, M. J. (2009). Structure of Sumatra and Its Implications for the Tectonic Assembly of Southeast Asia and the Destruction of Paleotethys. Island Arc, 18, 3-20. https://doi.org/10.1111/j.1440-1738.2008.00631.x 
Barber, A. J., Crow, M. J., \& Milsom, J. S. (2005) Sumatra: Geology, Resources and Tectonic Evolution. Geological Society, London, Memoirs, 31, 175-233.

https://doi.org/10.1144/GSL.MEM.2005.031.01.13

Berthé, D., Choukroune, P., \& Jégouzo, P. (1979). Orthogneiss, Mylonite and Non Coaxial Deformation of Granites: The Example of the South Armorican Shear Zone. Journal of Structural Geology, 1, 31-42. https://doi.org/10.1016/0191-8141(79)90019-1

Bishop, M. G. (2001). South Sumatra Basin Province, Indonesia: The Lahat/Talang AkarCenozoic Total Petroleum System. U.S. Department of the Interior. https://doi.org/10.3133/ofr9950S

Bouchez, J. L., Lister, G. S., \& Nicolas, A. (1983). Fabric Asymmetry and Shear Sense in Movement Zones. Geologische Rundschau, 72, 401-419. https://doi.org/10.1007/BF01822075

Brodie, J., Bartsch, I., Neefus, C., Orfanidis, S., Bray, T., \& Mathieson, A. C. (2007). New Insights into the Cryptic Diversity of the North Atlantic-Mediterranean 'Porphyra Leucosticta' Complex: P. olivii sp. nov. and P. rosengurttii (Bangiales, Rhodophyta). European Journal of Phycology, 42, 3-28. https://doi.org/10.1080/09670260601043946

Budiman, A., Priyono, A., Samodra, A., Mu’in, F., \& Latuconsina, M. (2011). Integrated Structural Modeling \& Seismic Attributes Analysis for Fractured Basement Reservoir Identification in Pangea Block, South Sumatera Basin, Indonesia. In International Petroleum Technology Conference (pp. IPTC-15222-MS). OnePetro. https://doi.org/10.2523/IPTC-15222-MS

Cameron, N. R., Clarke, M. C. G., Aldiss, D. T., Aspden, J. A., \& Djunuddin, A. (1980). The Geological Evolution of Northern Sumatra. In Proceedings of the 9th Annual Convention of the Indonesian Petroleum Association (pp. 149-187). Indonesian Petroleum Association. https://doi.org/10.29118/IPA.619.149.187

Cardozo, N., \& Allmendinger, R. W. (2013). Spherical Projections with OSXStereonet. Computers \& Geosciences, 51, 193-205. https://doi.org/10.1016/j.cageo.2012.07.021

Chenrai, P. (2012). DEM Application for Geological Structure Interpretation: A Case Study at the Koh Samui Area, Gulf of Thailand. World Applied Sciences Journal, 17, 1516-1520.

de Coster, G. L. (1974). The Geology of the Central and South Sumatra Basins. In Proceedings of the Indonesian Petroleum Association, 3rd Annual Convention (pp. 77-110). Indonesian Petroleum Association.. https://doi.org/10.29118/IPA.670.77.110

Gafoer, S., Amin, T. C., \& Pardede, R. (1994). Geological Map of the Baturaja Quadrangle (1011) Sumatra. Geological Research and Development Center.

Goscombe, B. D., Passchier, C. W., \& Hand, M. (2004). Boudinage Classification: EndMember Boudin Types and Modified Boudin Structures. Journal of Structural Geology, 26, 739-763. https://doi.org/10.1016/j.jsg.2003.08.015

Guttormsen, J. (2010). Naturally Fractured Basement Reservoirs: Using South Sumatra to Characterize the Challenges of Exploring and Exploiting Fracture Basement Reservoirs. In Proceedings of the 34th Annual Convention of the Indonesian Petroleum Association (pp. IPA10-G-183). Indonesian Petroleum Association.

Hall, R. (2014). The Origin of Sundaland. In Procedings of Sundaland Resources 2014 MGEI Annual Convention (pp. 1-25). Academia.

Handini, E., Setiawan, N. I., Husein, S., Adi, P. C., \& Hendarsyah (2017). Petrologi Batuan Alas Cekungan (Basement) Pra-Tersier di Pegunungan Garba, Sumatera Selatan. In Proceedings of Joint Convention Malang 2017. HAGI-IAGI-IAFMI-IATMI.

Heynekamp, M. R., Goodwin, L. B., Mozley, P. S., \& Haneberg, W. C. (1999). Controls on Fault-Zone Architecture in Poorly Lithified Sediments, Rio Grande Rift, New Mexico: 
Implications for Fault-Zone Permeability and Fluid Flow. Faults and Subsurface Fluid Flow in the Shallow Crust, 113, 27-49. https://doi.org/10.1029/GM113p0027

Hooker, J. N., Laubach, S. E., \& Marrett, R. (2018). Microfracture Spacing Distributions and the Evolution of Fracture Patterns in Sandstones. Journal of Structural Geology, 108, 66-79. https://doi.org/10.1016/j.jsg.2017.04.001

Idarwati, Purwanto, H. S., Sutriyono, E., \& Prasetyadi, C. (2018, December). Revealing Granitic Basement of Garba Hill, Muara Dua Region, South Sumatera Based on Landsat Images, Structure, and Petrography. IOP Conference Series: Earth and Environmental Science, 212, Article ID: 012041. https://doi.org/10.1088/1755-1315/212/1/012041

Khajavi, N., Quigley, M., \& Langridge, R. M. (2014). Influence of Topography and Basement Depth on Surface Rupture Morphology Revealed from LiDAR and Field Mapping, Hope Fault, New Zealand. Tectonophysics, 630, 265-284. https://doi.org/10.1016/j.tecto.2014.05.032

Li, J., Li, Z., Liu, S., Ran, B., Ye, Y., Deng, B., \& Sun, D. (2018). Kinematics of the Chengkou Fault in the South Qinling Orogen, Central China. Journal of Structural Geology, 114, 64-75. https://doi.org/10.1016/j.jsg.2018.06.008

Lister, G. S., \& Snoke, A. W. (1984). SC Mylonites. Journal of Structural Geology, 6, 617-638. https://doi.org/10.1016/0191-8141(84)90001-4

Marrett, R., \& Allmendinger, R. W. (1990). Kinematic Analysis of Fault-Slip Data. Journal of Structural Geology, 12, 973-986. https://doi.org/10.1016/0191-8141(90)90093-E

McCourt, W. J., \& Cobbing, E. J. (1993). The Geochemistry, Geochronology and Tectonic Setting of Granitoid Rocks from Southern Sumatra, Western Indonesia. Southern Sumatra Geological and Mineral Exploration Project, Directorate of Mineral Resources/ Geological Research and Development Centre.

McCourt, W. J., Crow, M. J., Cobbing, E. J., \& Amin, T. C. (1996). Mesozoic and Cenozoic Plutonic Evolution of SE Asia: Evidence from Sumatra, Indonesia. Geological Society, London, Special Publications, 106, 321-335. https://doi.org/10.1144/GSL.SP.1996.106.01.21

Meixner, J., Grimmer, J. C., Becker, A., Schill, E., \& Kohl, T. (2018). Comparison of Different Digital Elevation Models and Satellite Imagery for Lineament Analysis: Implications for Identification and Spatial Arrangement of Fault Zones in Crystalline Basement Rocks of the southern Black Forest (Germany). Journal of Structural Geology, 108, 256-268. https://doi.org/10.1016/j.jsg.2017.11.006

Metcalfe, I. (2011). Tectonic Framework and Phanerozoic Evolution of Sundaland. Gondwana Research, 19, 3-21. https://doi.org/10.1016/j.gr.2010.02.016

Metcalfe, I. (2013). Gondwana Dispersion and Asian Accretion: Tectonic and Palaeogeographic Evolution of Eastern Tethys. Journal of Asian Earth Sciences, 66, 1-33. https://doi.org/10.1016/j.jseaes.2012.12.020

Metcalfe, I. (2017). Tectonic Evolution of Sundaland. Bulletin of the Geological Society of Malaysia, 63, 27-60.

Mozley, P. S., \& Goodwin, L. B. (1995). Patterns of Cementation along a Cenozoic Normal Fault: A Record of Paleoflow Orientations. Geology, 23, 539-542. https://doi.org/10.1130/0091-7613(1995)023<0539:POCAAC>2.3.CO;2

Munasri, M., Mukti, M. M. R., Permana, H., \& Putra, A. M. (2015). Jejak subduksi Mesozoikum di Komplek Garba, Sumatra bagian selatan berdasarkan fosil radiolaria dan data geokimia. Prosiding Geoteknologi LIPI.

Peacock, D. C. P., Nixon, C. W., Rotevatn, A., Sanderson, D. J., \& Zuluaga, L. F. (2016). 
Glossary of Fault and Other Fracture Networks. Journal of Structural Geology, 92, 12-29. https://doi.org/10.1016/j.jsg.2016.09.008

Peccerillo, A., \& Taylor, S. R. (1976). Geochemistry of Eocene Calc-Alkaline Volcanic Rocks from the Kastamonu Area, Northern Turkey. Contributions to Mineralogy and Petrology, 58, 63-81. https://doi.org/10.1007/BF00384745

Priest, S. D. (1993). Discontinuity Size. In Discontinuity Analysis for Rock Engineering (pp. 150-196). Springer. https://doi.org/10.1007/978-94-011-1498-1_6

Priest, S. D., \& Hudson, J. A. (1981). Estimation of Discontinuity Spacing and Trace Length Using Scanline Surveys. International Journal of Rock Mechanics and Mining Sciences \& Geomechanics Abstracts, 18, 183-197. https://doi.org/10.1016/0148-9062(81)90973-6

Pulonggono, A., Haryo, S. A., \& Kosuma, C. G. (1992). Pre-Tertiary and Tertiary Fault System as a Framework of the South Sumatra Basin: Study of SAR Map. In Proceedings of the 21st Annual Convention, Indonesian Petroleum Association (pp. 339-360). Indonesian Petroleum Association.

Rawling, G. C., \& Goodwin, L. B. (2006). Structural Record of the Mechanical Evolution of Mixed Zones in Faulted Poorly Lithified Sediments, Rio Grande Rift, New Mexico, USA. Journal of Structural Geology, 28, 1623-1639.

https://doi.org/10.1016/j.jsg.2006.06.008

Risyad, M., Suta, I. N., \& Haris, A. (2017). Fault Assessment for Basement Reservoir Compartmentalization: Case Study at Northeast Betara Gas Field, South Sumatra Basin. AIP Conference Proceedings, 1862, Article ID: 030186.

https://doi.org/10.1063/1.4991290

Sagita, R., Sari, Q. C., Chalik, M., Rita, A., Waworuntu, R., \& Guttormsen, J. (2008). Reservoir Characterization of Complex Basement-Dayung. In Proceedings of the 32nd Annual Convention of the Indonesian Petroleum Association (pp. 259-270). Indonesian Petroleum Association. https://doi.org/10.29118/IPA.579.08.G.208

Sanderson, D. J., \& Nixon, C. W. (2015). The Use of Topology in Fracture Network Characterization. Journal of Structural Geology, 72, 55-66. https://doi.org/10.1016/j.jsg.2015.01.005

Simpson, C. (1985). Deformation of Granitic Rocks across the Brittle-Ductile Transition. Journal of Structural Geology, 7, 503-511. https://doi.org/10.1016/0191-8141(85)90023-9

Sunarjanto, D., \& Widjaja, S. (2013). Potential Development of Hydrocarbon in Basement Reservoirs in Indonesia. Indonesian Journal on Geoscience, 8, 151-161. https://dx.doi.org/10.17014/ijog.8.3.151-161

Torsvik, T. H., Van der Voo, R., Preeden, U., Mac Niocaill, C., Steinberger, B., Doubrovine, P. V. et al. (2012). Phanerozoic Polar Wander, Palaeogeography and Dynamics. Earth-Science Reviews, 114, 325-368. https://doi.org/10.1016/j.earscirev.2012.06.007

Van Hinsbergen, D. J., Kapp, P., Dupont-Nivet, G., Lippert, P. C., DeCelles, P. G., \& Torsvik, T. H. (2011). Restoration of Cenozoic Deformation in Asia and the Size of Greater India. Tectonics, 30, 5-31. https://doi.org/10.1029/2011TC002908

Wajzer, M. R., Barber, A. J., \& Hidayat, S. (1991). Accretion, Collision and Strike-Slip Faulting: The Woyla Group as a Key to the Tectonic Evolution of North Sumatra. Journal of Southeast Asian Earth Sciences, 6, 447-461.

https://doi.org/10.1016/0743-9547(91)90087-E 